\title{
Reinforcement of Islamic education in the revolution era of society 5.0
}

\author{
Pujii,* \\ ${ }^{1}$ University of Muhammadiyah Malang, Indonesia \\ *Corresponding author: pujifinapuji@gmail.com
}

KEYWORDS

reinforcement

Islamic education learning

society 5.0

SUBMITTED 21 Dec 2020

REVISED 20 Jan 2021

ACCEPTED 15 Feb 2021

\begin{abstract}
Islamic education in society 5.0 faces various complex problems, lack of adequate resources, lack of teachers', lecturers', and educational personnel's competence. Addiction to technology causes students to lose their character and morals. Increasing the competence of teachers and students is significant to face the challenges. The three main pillar components that need to be possessed by each component are (a) ability to solve problems, (b) ability to think critically, (c) ability to be creative. This study aimed to describe the implementation of the strengthening of Islamic Education learning in the era of community revolution 5.0. This research uses a qualitative approach with the type of literature study research. The author will explore the data according to the discussion in this study, then collect them for analysis. Data analysis was carried out in three stages: data reduction, data presentation, conclusion drawing, or data verification. The study results show that the reinforcement of Islamic Education learning in the community revolution era was 5.0. by integrating Islamic religious values into KDP values. This integration is to overcome the children's moral crisis in the era of community life 5.0. The use of digital technology as a learning medium is the right step to balance the needs of society 5.0. Thus, the welfare and quality of life of the people increases. Especially the needs of all elements in the field of education.
\end{abstract}

(c) The Author(s) 2021.

\section{INTRODUCTION}

Education is currently experiencing rapid development. These changes are in line with increasingly advanced technology due to learning systems and methods supported by digitalization technology. This development marks the determination of the era of globalization (Silfia, 2018). The determination globalization era marks the industrial era 5.0, which emerged due to the impact of the 4.0 revolution (Indramawan \& Hafidhoh, 2019).

One of the elements affected by the challenges of the 5.0 industrial revolution is the education sector. The rapid and massive development of technology requires the education sector to adapt to the digitalization of the growing education system. The right solution in facing the challenges of the 5.0 industrial revolution era needs to be carefully prepared to be in line with the times. This situation is because the style of community life in the era of 5.0 is a conception of people who are already literate towards Information and Communication Technology (ICT). Some of the skills students need to master include: creative thinking, innovation, critical thinking, communication skills, and collaboration skills (Sukarno, 2020).

On the other hand, according to Andreja, the industrial revolution 4.0 and society 5.0 are real. The movement is oriented towards increasingly sophisticated and advanced information and technology (Rojko, 2017). Thus, it also encourages the world of education, including Islamic Educa- tion, to create innovations in the learning process that is carried out.

PAI learning is a teacher's effort to educate students who learn about Islamic Education subjects. The goal is to increase students' understanding, faith, appreciation, and practice of Islam to become Muslim who believe and fear Allah SWT and have noble morals in their personal, social, national, and state life (Bahtiar, 2017). However, due to the development and advancement of the era of the technological revolution, it had a tremendous effect on changing students' attitudes. They are increasingly likely to be addicted to gadgets, cyberbullying and even cause moral or moral decline (Umro, 2020). Thus, PAI teachers are expected to think of the right solution to overcome these problems.

As the agent of knowledge transfer, the PAI teachers seek to reinforce the PAI learning, where the strengthening can be developed with the PAI learning model based on digital media. It can be done by utilizing various technologies developed in that era, such as the internet, computers, laptops, netbooks, wifi, gadgets, smartphones, tablets and others similar (Nugraha, Supriadi, Anwar, 2014).

This effort was made to answer the offset the impact of the emergence of the 4.0 industrial revolution, which has created a dependence on digital technology to increase human life quality. This effort is in line with the concept of Society 5.0 adopted by the Japanese government, namely as an antipathy to global problems arising from the industrial revolution 4.0 [6]. Simultaneously, the efforts answer 
the challenges that arise due to the industrial revolution 4.0 and globalization's disruption, where these events are marked by world conditions that are full of turmoil, uncertainty, complexity, and ambiguity (Putra, 2019).

There are several studies related to the reinforcement of PAI learning in society 5.0 era; they are: Nugraha, Supriadi, Anwar (2014), which examined digital-based Islamic education learning (a descriptive study of Islamic Education learning at SMA Alfa Centauri Bandung); Priatmoko (2018) who examines the existence of Islamic education in the 4.0 era; Putra (2019) who examines the challenges of Islamic education in facing society 5.0; Priyanto (2020) who examines Islamic education in the era of the industrial revolution 4.0; Umro (2020) who examines the challenges of Islamic religious education teachers in facing the Society 5.0 era; Of all the studies that have been mentioned, all explain the portrait of the dynamics that occurred in the industrial era 4.0 and society 5.0, so the focus of the problem formulation in this study is how to implement strengthening Islamic Education learning in the era of community revolution 5.0.

\section{METHOD}

This research uses a qualitative approach with the type of literature study research. The author chose a qualitative approach in this study because he wanted to describe in-depth the implementation of strengthening Islamic Education learning in the era of community revolution 5.0. Meanwhile, the literature study was chosen because the researcher wanted to explore data related to reinforcement of Islamic Islamic education learning in the era of society 5.0.

Data obtained from various kinds of relevant books and literature, documents, journals, articles, and information from print and other electronic media were collected, selected and grouped, then discussed and analyzed. Data analysis was carried out in three stages: data reduction, data presentation, and conclusions drawing, as explained by Miles and Huberman (Haris \& Amin, 2020).

\section{RESULTS AND DISCUSSION}

\subsection{The Urgency in Learning Reinforcement}

Positive reinforcement to students is a significant stage in the learning process. The aim is to increase students' motivation to learn and control their behaviour inside and outside the learning process. The provision of positive reinforcement is expected to make students' learning attitudes better to create a better generation of the nation for the future (Syarifudin, 2016). Further, Syarifudin concluded that reinforcement is the teacher's response to the behaviour or actions that have been done by students. The goal is to increase student enthusiasm for learning. By giving a positive response, students feel appreciated for what they have done.

Thus, students will be motivated to repeat their actions. Rohani, Maman, and Sulha (2019) said that "Reinforcement of every response, both verbally or non-verbally, as a part of the modification responses from teacher to provide information / feedback for the recipient (student) for his actions as an act of encouragement or correction, or reinforcement is a response to a behaviour that can increase the repetition of the behaviour." Regarding the quote, the teacher must give reinforcement in the learning process he does. The treatment is given continuously as an effort to encourage students to behave positively (Rohani, Maman, Sulha, 2019).

\subsection{Main Purposes of PAI Learning}

Islamic religious education (PAI) learning in educational institutions is ubiquitous. This method is taught in schools both in public schools and in religion-based schools, generally called madrasah (Susanto \& Rahmatullah, 2020). Islamic religious learning is a material that must be present at every level of education from an early age level to the college level.

This material is translated into four subjects in a madrasa-level school institution, namely Aqidah morals, AlQur'an Hadith, Jurisprudence, and Islamic Cultural History. Whereas at the public school level, it is only described in one subject, namely Islamic religious education and character (Lubis, Yusri \& Gusman, 2020). Therefore, this material becomes the basis for Islamic Education teachers to teach it to students.

The purpose of PAI learning material is to instil spiritual values in students. Its existence has shaped the personality of a person who is Muslim to believe and obey Allah SWT. Therefore, the material he teaches is not only in the form of theoretical or concept studies but also in practice. Thus, it requires Muslims to be skilled and accustomed to carrying out all worship series taught by religion by Islam (Ali, 2018).

\subsection{The Dynamic of Society 5.0 and Its Education Forms}

Society 5.0 was first p by the Japanese government proposed as a development towards the 4.0 industrial revolution. Industrial Revolution 4.0 is considered capable of degrading humans' role in all aspects of life. Society 5.0 is a community with a human-centred concept of society in all aspects of life and is technology-based in every activity undertaken (Putra, 2019). Thus, people are required to solve all social problems and challenges that occur by utilizing digital technology. Meanwhile, internet service is the primary and most basic access to support digitalization technology that is utilized by the 5.0 community.

Likewise, all financial transactions carried out by society 5.0 to meet their needs are done online, such as online shopping, online electricity payments, PDAM, phone credits, and many others. All of them have the ultimate goal: improving human life's welfare and quality (Nopitasari \& Farida, 2020). Thus, the 5.0 society revolution is a human era that can synergize digital technology with social life's reality in solving existing social problems. The aim is to balance progress in the economy with the various social problems that arise.

Essentially, the concept of society 5.0 is a life pattern for people who can solve various kinds of social problems that arose in the era of the industrial revolution 4.0. One of them is by taking advantage of various kinds of innovations created in the era of the industrial revolution 4.0. The goal is to strengthen the existence of Islamic Education learning in that era. The use of digital technology such as the internet on things (internet for everything), artificial intelligence, big data (large amounts of data), and the use of robot power is a characteristic feature of people's life 5.0. The goal is as a means to improve the quality of human life $(\mathrm{Pu}-$ tra, 2019). Thus, the educational aspect has undergone a significant transformation. 
The form of education described in society 5.0 requires students to solve complex problems, have critical thinking, and have high creativity. As a result, students in the future are required to be able to think at a high level known as HOTS (High Order Thinking Skill) as an effort to prepare a generation that is reliable and able to face the challenges and advances that occur in the community life 5.0 and the industrial revolution 4.0 (Nopitasari \& Farida, 2020).

\subsection{The solution to PAI Learning Issues in Society 5.0 Or- der}

The problem that arises today is that the world of education is experiencing a complex problem; the rapid progress of technology rolled out by the era of the industrial revolution 4.0. Before the problem can be resolved, new problems arise, namely the emergence of the concept of society 5.0, which can be translated into society 5.0 [6].

As stated by A. Malik Fajar, quoted by Pristian Hadi Putra, he stated that there are three tough challenges currently facing the world of education: firstly, the educational field's effort in protecting itself from crisis attacks and keeping the educational achievement. Secondly, the global atmosphere in education allows competition, both on a regional, national, and international scale. Thirdly, Making changes and adjustments to the national education system that supports the education process to be more democratic considers the diversity of needs or conditions of regions and students and encourages increased participation or participation in elements of society (Putra, 2019).

Related to Malik Fajar's statements, the PAI teacher faces many problems. Among them are the excessive pressure exerted by PAI in the past on cognitive aspects, thus ignoring other aspects. This occurrence has resulted in split personalities because they only focus on intellectual intelligence rather than emotional intelligence. Also, the lack of human resources in the education sector is technology literate, causing educators (teachers, lecturers, or other educators) to be technology literate (Umro, 2020).

Inability to master information and communication technology in the human resource aspect of education can affect teachers' or education personnel's ability to access vital information in the world of education itself. This issue weakens the quality of existing human resources so that students may underestimate teachers. The result will be a crisis in a person's personality or a loss of character in students; for example, there was a viral event on social media about a student's teacher being challenged. Simultaneously, morals are essential and urgent to develop human resources (Aminudin, 2019).

The solutions offered to deal with various problems in Islamic Education learning in society 5.0 are a lot. One of them is the opinion expressed by Nuryadin, quoted by Noor Amirudin, explaining that strategic steps are needed to deal with the problems that occur. Among them, the development and improvement of the quality of existing human resources, the transformation of digital technology-based infrastructure, and optimization of digital-based learning media (Aminudin, 2019).

\section{CONCLUSION}

The conclusion to answer the problem formulation in this study is that the reinforcement of Islamic Education learning in the revolution era of society 5.0 done by integrating
Islamic religious values into KDP values. This action was done to overcome the moral crisis of the nation's children that occurred in the era of community life 5.0.

The use of digital technology as a medium of learning is the right step to balance the needs of society 5.0. Thus, the welfare and quality of life of the people increases. Especially the needs of all elements in the field of

\section{REFERENCES}

Ali, M.D. (2018). Pendidikan Agama Islam. Jakarta: PT. Raja Grafindo Persada.

Aminudin, N. (2019). Problematika pembelajaran pendidikan agama Islam di era digital," Prosiding Seminar Nasional Prodi PAI UMP.

Bahtiar, A.R. (2017). Prinsip-prinsip dan model pembelajaran pendidikan agama Islam. Jurnal Tarbawi, 1(2).

Haris, A. \& Amin, K. (2020). Model pembelajaran agama Islam berbasis pesantren di Panti Asuhan Al-Ma'wa Sumberpucung Malang, Ta'dibuna.

Indramawan \& Hafidhoh. (2019). Pendidikan Karakter Sebagai Upaya Meningkatkan Semangat Belajar. SEMDIKJAR. 3.

Jumarudin, J., Gafur.A. \& Suardiman, S.P. (2014). Pengembangan model pembelajaran humanis religius dalam pendidikan karakter di sekolah dasar, Jurnal Pembangunan Pendidikan: Fondasi dan Aplikasi, 2(2).

Khazanah. U \& Hernia. H. (2019). Membangun karakter siswa melaui literasi digital dalam menghadapi pendidikan abad 21 (revolusi industri 4.0), Prosiding Seminar Nasional Pendidikan Program Pascasarjana Universitas Palembang 3(1).

Lubis, M., Yusri, D., \& Gusman, M. (2020). Pembelajaran Pendidikan Agama Islam Berbasis E-Learning. Fitrah: Journal of Islamic Educattion (FJIE) 1(1).

Majid \& Andayani. (2015). Pendidikan Agama Islam Berbasis Kompetensi; Konsep dan Implementasi Kurikulum 2004. Bandung: Remaja Rosdakarya.

Nopitasari \& Farida F. (2020). Are we ready for communities 5,0 ?, Proceeding IAIN Batu Sangkat 1(3).

Nugraha, M.S., Supriadi, U. \& Anwar, S. (2014). Pembelajaran PAI Berbasis Media Digital (Studi Deskriptip terhadap Pembelajaran PAI di SMA Alfa Centauri Bandung). Jurnal Pendidikan Agama Islam-Ta'lim 12(1).

Putra, P.H. (2019). Tantangan Pendidikan Islam dalam Menghadapi Society 5.0. Jurnal Islamika: Jurnal IlmuIlmu Keislaman; 19(2).

Rizqy, S.N. (2019). Pengintegrasian pendidikan berkarakter berbasis multikultural dalam pembelajaran bahasa Indonesia. Jurnal Senasbas, 3(2).

Rohani, Maman, Sulha. (2019). Pengaruh pemberian penguatan oleh guru terhadap hasil belajar siswa dalam pembelajarn pendidikan kewarganegaraan, Jurnal Pendidikan dan kewarganegaraan (JPKN), 3(2).

Rojko, A. (2017). Industry 4.0 Concept: Background and Overview. ECPE European Center for Power. Electronics e.V. Vol. 11. (Nuremberg, Germany)

Silfia, M. (2018). Penguatan pendidikan karakter dalam menghadapi era revolusi industri 4.0. Digital Library UNIMED.

Sukarno, M. (2020). Penguatan Pendidikan Karakter Dalam Era Masyarakat 5.0. Prosiding Seminar Nasional Milleneial 5.0 Fakultas Psikologi UMBY. 
Susanto, E.P. \& Rahmatullah. (2020). Optimalisasi Pembelajaran Pendidikan Agama Islam (PAI) Melalui Google Classsroom, Jurnal Piwulang, 2(2).

Syarifuddin, C.R. (2016). Pengaruh pemberian penguatan positif terhadap sikap belajar peserta didik pada mata pelajaran bahasa Indonesia di MI Darul Istiqomah Kecamatan Pattalassang Kabupaten Gowa. AULADANA: Jurnal Pendidikan Dasar Islam, 3(2).
Umro, J. (2020). Tantangan Guru Pendidikan Agama Islam Dalam Menghadapi Era Society 5.0, Jurnal Al-Makrifat, 5(1). 